\title{
Stakeholder Power and Engagement in an English Seaside Context: Implications for
}

\section{Destination Leadership}

Victoria Kennedy (Liverpool Hope University) and Marcjanna M. Augustyn (University of Hull)

\begin{abstract}
Purpose - The purpose of this paper is to examine stakeholder power and engagement within an increasingly competitive English seaside resort setting. It aims to adopt a structuralist and functionalist perspective and develop an enabling conceptualisation of power that incorporates structural and agency components in stakeholders' reasons for engaging. Based on the conceptual interdependencies between stakeholder power and engagement, this study aims to present the limitations of previous studies on destination leadership in this area, and this paper also seeks to discuss implications for destination leadership.
\end{abstract}

Design/methodology/approach - As a qualitative and exploratory study, mixed-method research was adopted using questionnaires and semi-structured interviews with destination stakeholders from a prominent tourism action group. The primary research was carried out in an English seaside resort between 2010 and 2011. Data are used to draw a stakeholder map as a visual tool.

Findings - Eight elements of enabling power are confirmed to be of importance in identifying stakeholder power and engagement. The level of power varies depending on stakeholders' position within a network. These findings direct attention towards adopting a complexity leadership approach in an increasingly competitive destination environment.

Research limitations/implications - The paper focuses on an English seaside resort, although results can be transferred to other similar-sized destinations where the focus is on local tourism policy development.

Originality/value - The paper provides an innovative conceptualisation of power in stakeholder theory by drawing primarily on a sociological understanding of power as an enabler and not as an inhibitor for development, leadership and change in seaside resorts. This paper uses leadership theories to interpret data and infer implications for destination leadership.

Keywords Leadership, Stakeholder engagement, Power, Tourism policy, Seaside tourism

Paper type Research paper

\section{Introduction}

English seaside resorts are facing challenging times attributed mainly to the overall decline of their appeal, changing tourist demand patterns, and changing national and regional 
tourism structures and support mechanisms (Agarwal, 2002; Beatty and Fothergill, 2003; Gale, 2005; Dinan et al., 2011). Since seaside resorts are often economically dependent on tourism through historical development (Beatty et al., 2010), addressing these problems is paramount to ensuring socio-economic prosperity of seaside resorts. Consistent with the contingency theory, among several aspects of adapting to this new competitive landscape (that include acquiring new knowledge, innovation, and adopting new patterns of behaviour), a consideration of destination leadership is central to developing local tourism policies that can address the challenges presented by the changing destination environments. Indeed, prominent organisational change scholars (e.g. Kanter, 1983; Kotter, 1995; Adair, 2002; Heifetz et al., 2009) argue that since change is a human process, appropriate leadership is crucial to successful transformation. Similarly, tourism scholars (e.g. Reed, 1997; Go and Gover, 2000; Sheehan and Ritchie, 2005; Varra et al., 2012) stress that appropriate leadership is essential in destination planning and management, due to the heterogeneity and complexity of destination stakeholder relations.

Recent studies advocate a collaborative approach to local tourism policy making and recognize the importance of stakeholder engagement (i.e. the different means of stakeholder contribution to tourism policy development) (Svensson, 2005; Timur and Getz, 2008; Kimbu and Ngoasong, 2013). Little is known, however, which leadership approaches could be adopted within this context to secure a prosperous future of tourism destinations. Indeed, our literature review indicates that there are only a few in-depth studies that analyse destination leadership, all of which focus on destination management organisations as destination leaders. While some studies provide interesting insights into aspects of transactional leadership (Haven-Tang and Jones, 2012) or servant leadership (Varra et al., 2012) within the context of tourism destinations, organisational leadership literature draws attention to investigating the viability of adopting other leadership approaches within specific contexts of 
tourism destinations. In order to deduce whether a particular leadership approach is relevant to these contexts, it is necessary to understand power relationships and stakeholder engagement within a specific destination. Indeed, several authors argue that power and leadership are related concepts in that leadership, being associated with processes of influencing others towards achieving common purpose, can be determined by the power relationships that exist between leaders and followers (Burns, 1978; Northouse, 2004; Kotter, 2007; Haven-Tang and Jones, 2012). With this context, Carmo (2011) states that "leadership expresses a relation of influence, a kind of 'influencing power', and typically it is supposed to be associated to (the holders of) certain positions, within organizations". Burns (1978) argues, however, that leaders are particular type of power holders and stresses the importance of engaging people.

Given the conceptual interdependencies between power, engagement and leadership and the limitations of previous studies on destination leadership, this paper examines stakeholder power and engagement and their implications for destination leadership within an increasingly competitive English seaside resort setting. It adopts structuralist and functionalist perspectives and advocates a positive, enabling conceptualisation of stakeholder power based on the notions of Foucault and Arendt (Foucault, 1980a, 1980b, Arendt, 1970, 1998, Allen, 2003).

\section{Stakeholder Power and Engagement}

Viewed primarily from spatial and institutional perspectives (Reed, 1997; Sheehan and Ritchie, 2005; Bramwell and Meyer, 2007; Byrd, 2007, Stevenson et al., 2008), prior research on destination power relationships have mainly adopted resource dependence and exchange perspectives (see for example, Doorne, 1998; Dredge and Jenkins, 2003; Treuren and Lane, 2003; Pforr, 2006; Anastasiadou, 2008; Beritelli and Laesser, 2011) and rarely 
considered human and social aspects of stakeholder interaction, influence and engagement with local tourism policy development.

The resource dependence perspective proposes that power emanates from controlling resources that are needed to pursue certain goals (Pfeffer, 1981). This traditional pluralist perspective considers power as being an oppressing and negative entity influencing individuals (Mitchell et al., 1997), where "A has power over B to the extent that he can get B to do something B would otherwise not do" (Dahl, 1957, p. 202-203). Two key assumptions are implicit in this conception: that power can be possessed, and that power is regarded as a commodity that individuals can acquire, exchange, share or delegate away (Kearins, 1996). A primary interpretation is that power is a fixed and static relationship with one actor exerting pressure over another, often associated with resource control in a network (Rowley, 1997). This traditional perspective can be attributed to a structuralist conception with a focus on structural factors set within a system of values and beliefs, making power a reified construct exercised by structures rather than individuals (Parsons, 1968, Kearins, 1996).

Such a conceptualisation of power gives little consideration to social aspects of stakeholder interactions and relationships, attributed to functionalism that refers to the intention of individuals to engage and their actual behaviour in this context (Kearins, 1996). From a tourism perspective, functionalist approaches are relevant as they can denote how the tourism system operates, but also fail to adequately identify the factors that structure and inform it. To address this shortcoming, functionalist approaches need to be supported by structuralism taking greater consideration of the factors that inform the tourism system and explain its dynamics (Dann and Cohen, 1991). Using therefore a structuralist and functionalist perspectives, and based on the notions of Foucault and Arendt (Foucault, 1980a, 1980b, Arendt, 1970, 1998, Allen, 2003), this paper advocates a positive, enabling conceptualisation of stakeholder power that is viewed as an empowerment of individuals 
rather than an oppressive power where one individual influences another in a negative fashion. Inherent in an enabling power conceptualisation is the recognition of interrelatedness of stakeholders and their embeddedness within their environments and social networks as seen from both structuralist and functionalist perspectives (Granovetter, 1985).

\section{Eight elements of enabling power}

A review of literature in the areas of stakeholder theory, Foucault and Arendt's discussion on power, as well as structure and agency, indicates that enabling power can be conceptualised in terms of eight different, yet complementary and interlinked elements: stakeholder role sets, stakeholder salience, associative relationships, structure, subjectivity, agency, social relations, and visibility.

Informed by their job, education, social relations and interests (business and personal), every individual stakeholder can be a member of several stakeholder groups (Freeman, 1984). These groups may potentially have different interests at heart and varying foci, causing conflict when stakeholders are facing competing roles. Such stakeholder role sets are unique to every stakeholder and influence their behaviour. They also determine stakeholder salience, as perceived by others, which is informed by the type of relationship a stakeholder has with others. Interesting for this paper is the concept of associative relationships of stakeholders denoting the interests of stakeholders and their motivation to engage or get involved. Swedberg (2005) identifies three types of associative relationships: 1) market exchange (compromise between opposed interests); 2) Zweckverein (instrumental associations based on material interests); 3) Gesinnungsverein (associations devoted to a cause). The type of associative relationship is informed not only by the previously mentioned factors of stakeholder role sets and stakeholder saliency but also by structure, subjectivity, agency, social relations and visibility. Structure, defined as a pre-existing social structure that 
one is born into and surrounded by in everyday life, is largely undetected by an individual (Bourdieu and Wacquant, 1992; Thiele, 1997). Such social structures are to a certain extent static in that an individual does not have the immediate ability to change these social structures readily, though this can be achieved over a period of time and sustained action. Although social network analysis per se was not conducted for the purpose of this paper, a more detailed discussion on the dynamics of social networks and stakeholder relationships can be found in the literature (e.g. Scott et al., 2008, Del Chiappa and Presenza, 2013). Foucault's (1980b) notion of subjectivity provides further insight into an individual's position, where individuals are embedded in social relations by being a subject whilst at the same time being in a position to influence this subjectivity (Allen, 2003). A premise for subjectivity is agency which is defined as an individuals' capacity to act (Sibeon, 1999) denoting that, within the constraints of the social structures they are embedded in, individuals have the ability to create something new. Agency and structure in the context of an enabling conceptualisation of power is dialectical where primacy cannot be given to one approach over the other. The embeddedness of stakeholders is further defined by their social relations (relationships one has with other tourism stakeholders). As a final element of an enabling power, visibility of stakeholders gives an insight to an individual's interaction and engagement with others, providing a platform for considering visible as well as non-visible participation or engagement in seaside tourism.

This paper argues that stakeholder power is made up of all or a combination of all these elements. While individually each element is limited in conceptualising stakeholder power, collectively there is scope to consider a comprehensive and encompassing enabling interpretation of stakeholder power and engagement in an English seaside tourism context. Given the above considerations, for the purpose of this paper, power is defined as the ability of a person or group (e.g. stakeholders within a network) to influence tourism policy 
development in a resort, while stakeholder engagement refers to different means of stakeholder contribution to tourism policy development, including direct physical attendance at meetings, their contributions to meetings by email, telephone, or other means of communication should physical attendance not be possible, and general involvement in tourism policy development.

\section{Tourism Destination Leadership}

Tourism literature emphasises the need for effective destination leadership in improving destination performance (e.g. Wilson et al., 2001; Pechlaner and Tschurtschenthaler, 2003; Powell, et al., 2009; Wang, et al., 2011; Ottenbacher and Harrington, 2013). There are, however, few studies that consider destination leadership in greater depth, particularly when compared with the number of studies that analyse destination management and governance. Our search for papers that include terms of "destination" and "leadership" within academic journal abstracts of five databases (Science Direct, EBSCO, Emerald, SwetsWise and Taylor and Francis Online) has returned only 19 relevant papers while a search for papers on "destination" and "management" in the same databases has returned in excess of 500 relevant papers.

Although our understanding of destination management and governance can provide some insights into destination leadership, eminent leadership scholars distinguish between the concepts of "management" and "leadership". In his seminal article and a book of the same title, What Leaders Really Do, John P. Kotter $(1990,1999)$ argues that while management and leadership are complementary systems of action, they differ in that "management is about coping with complexity" (by bringing order and consistency to organisational activities through planning, organising, and controlling) and "leadership is about coping with change" (by setting a vision and inspiring people) (Kotter, 1990, p.104). 
This perspective on management and leadership is particularly relevant to the context of this study (i.e. an English seaside resort that needs to adapt to the changing business environment) as it emphasises the importance of effective leadership in achieving change and the importance of power and empowerment that are essential to leading change (Kotter, 1995, 2007). However, leadership literature emphasises that leadership approaches have to be carefully chosen as their effectiveness depends on a range of variables including the source and type of power, the relations with the followers and situational factors (see for example Tannenbaum and Schmidt's (1958) Leadership Continuum Theory, Fiedler's (1967) Leadership Contingency Model, and Hersey and Blanchard's (1969, 1977) Situational Leadership Theory).

Consistent with this view, Burns' (1978) distinction between transactional and transformational leadership (first applied in organisational leadership context by Bass, 1985), is of particular relevance to the focus of this study. Indeed, the resource-driven transactional leadership assumes that the purpose of interaction between leaders and followers is an exchange of valued things. Here, possession of resources constitutes the major source of influencing power. In contrast, the value-driven transformational leadership assumes that individuals transcend their own self-interest and engage with others to pursue common goals that satisfy their higher level intrinsic needs. Here, "power bases are linked not as counterweights, but as mutual support for common purpose" (Burns, 1978, 20).

Although transformational leadership is frequently associated with charismatic individuals who bring about effective change (Bass, 1985; Den Hartog et al., 1999; Knippenberg and Sitkin, 2013), recent organisational leadership literature directs our attention to socially constructed forms of shared leadership that could provide viable alternatives to the individual transformational leadership. According to Pearce (2004) and Evaggelia and Vitta (2012) shared leadership, embedded in a specific context, is a dynamic, 
interactive process that engages all members of a group in concurrent reciprocal influence processes. The main types of socially constructed forms of shared leadership include shared transformational leadership (Hallinger, 2003; Briggs, 2005; Locke, 2007), complexity leadership (Uhl-Bien et al., 2007; Onyx and Leonard, 2010), network leadership (Balkundi and Kilduff, 2006), and distributed leadership (Bennett et al., 2003).

Since the choice of an appropriate destination leadership approach is determined by situational factors, this paper examines stakeholder power and engagement within an increasingly competitive English seaside resort setting and discusses implications for destination leadership.

\section{Methodology}

Based on an intermediate philosophical position of being structuralist as well as functionalist, the study is based on a mixed-method research approach (Woolley, 2009) that uses a questionnaire and semi-structured interviews for data collection. It is designed to be an exploratory and qualitative study seeking to examine stakeholder power and engagement within an English seaside resort setting whilst also exploring implications for destination leadership.

This study focuses on Scarborough, the first English seaside resort and administrative centre for the Borough of Scarborough that covers an area of around 330 square miles, has 43 miles of coastline and includes three principal towns: Scarborough, Whitby and Filey (Scarborough Borough Council, 2004; Audit Commission, 2009). Scarborough town is the largest centre of population within the Borough with an estimated resident population of 51,660 (North Yorkshire County Council, 2010).

Like many England's seaside resorts, Scarborough has faced tough challenges over the last couple of decades. Declining tourist numbers and an overall decline of the resort have 
resulted in Scarborough adopting regeneration strategies, mainly funded and guided by Yorkshire Forward, the area's Regional Development Agency (RDA) in the 2000s. However, coastal tourism is still a large part of the local, regional and national economy in the UK. For Scarborough Borough this equates to approximately 7.5 million visitors annually with an estimated spend of $£ 300 \mathrm{~m}$ per year (Welcome to Yorkshire, 2011). The disbanding of the RDAs has impacted upon how tourism is organised and the introduction of the new Local Enterprise Partnerships (LEP) sees Scarborough as part of the York and North Yorkshire region. Scarborough Borough Council would now have links with the East Riding and Hull LEP to take forward a regeneration package which focuses on the coast (York and North Yorkshire LEP, 2010). Unlike in other popular seaside resorts, there is no dedicated Destination Management Organisation (DMO) in Scarborough. Historically, tourism development was a public sector concern managed by Scarborough Borough Council, although with the shifts in funding allocations, the disbanding of the RDAs and general budget cuts, tourism was moved towards a more regional level and is now a concern for the Local Enterprise Partnerships.

For the purpose of this study, data was collected between July 2010 and April 2011 using members of the Scarborough Forum for Tourism (an action group formed in 1995 under the Town Team of Scarborough Borough Council) as the sample population. The Forum brings together various tourism and tourism related businesses and looks at tourism as a whole in Scarborough. Initially a paid membership group, the Forum is now free and open to the public and it is run by volunteers who are active in the community based on their personal or business interest in Scarborough tourism.

Data collection followed a sequential mixed design, where quantitative and qualitative strands followed in a chronological order, building upon each other and providing scope to evolve and change as the research progressed (Teddlie and Tashakkori, 2009). 
A self-administered online questionnaire was emailed to all Scarborough Forum for Tourism members in July 2010 using a census approach, counting all elements of a population (167 respondents) (Cooper and Schindler, 2001). This generated 37 useable responses. The questionnaire comprised 40 questions, including six routing or filter questions designed to further explore contextual questions and to minimise confusion for respondents if a particular question did not apply to them (Finn et al., 2000). The aim of this study guided the selection of questions. The questionnaire was structured around the eight elements of enabling power. A mix of attitudinal, open ended and contextual closed questions were used. Open ended questions, such as (Q2) Why do you attend Forum for Tourism meetings? and (Q15) Who do you think is responsible for tourism development in Scarborough?, were used to gain respondent's opinion of a particular area of concern (i.e. Q2 = social relations, Q15 = stakeholder salience) and a deeper insight into their relationships. Scaled, attitudinal questions followed a seven-point Likert scale (Lehmann and Hulbert, 1972; May, 2001) and tested a series of attitudes concerning stakeholder power and engagement in a seaside resort setting. Example attitudinal questions include: (Q10) How important is it that you know the people who attend the Forum? $(1=$ very important, $7=$ very unimportant $)(\mathrm{Q} 10=$ associative relationships), and (Q21) How valued do you feel your contribution is to the Forum $?(1=$ very valued, $7=$ very unvalued $(\mathrm{Q} 21=$ stakeholder role sets $)$. Other attitudinal questions asked respondents to rate their agreement with a number of statements: (Q9) It is expected of me to show an interest in the Forum. $(1=$ strongly agree, $7=$ strongly disagree $)$ (Q9 = subjectivity). The questionnaire also included a section dedicated to demographics. Following the questionnaire data analysis, 13 semi-structured telephone interviews were conducted in April 2011 using snowball-sampling that followed its course until no new names were mentioned by respondents and the data converged (Patton, 2002). The interviews were non-standardised and semi-structured with open-ended questions, allowing for an 
unprompted response from interviewees. The interviews were used to validate and corroborate findings of the questionnaire and to deepen the insight into their relationships and connections within the Forum as well as the Scarborough tourism industry. Based on the findings of the questionnaire, a link between attendance and engagement at meetings emerged which influenced how the telephone interviews were developed - Group 1 Engagement and Attendance, and Group 2 Engagement and Non-attendance. At the beginning of each interview both categories were read out to respondents who were asked to categorise themselves belonging to either Group 1 or 2.

For Group 1 the interview questions focused on the level of their engagement; which committees are important and attended by themselves; the length of their involvement and reasons for getting involved; personal expectations and attendance at Forum meetings; and their perception of others in the Forum environment. For Group 2 the interview questions considered similar issues with the exception that specific questions were included to investigate reasons for non-attendance, whether non-attendance has any effect on their influence or engagement, and what would encourage them to attend meetings. In addition, both Groups were asked whom they thought the most important person in the Forum and to give reasons why they thought this person is most important.

Stakeholder mapping was used to visualise the findings and data generated from the questionnaire and the telephone interviews, showing the relationships between attendees of the Scarborough Forum for Tourism and also providing an insight into other relationships these stakeholders may have, focusing on the membership/attendance of different groups and committees at a local level. An analysis of respondent's linkages at the local level can provide a deeper insight into their influence and visibility. Stakeholder maps were created using the Pajek social network analysis software program (De Nooy et al., 2005), though social network analysis per se was not undertaken. 


\section{Findings}

An analysis of the qualitative study results indicate that the eight elements of enabling stakeholder power are highly interlinked and that they are related to stakeholder engagement. Furthermore, power and engagement are influenced by a range of factors, as illustrated below.

Stakeholder role sets are informed by stakeholder's business and personal interests in the local tourism industry, where the agenda of the Forum meetings and the opportunity for decision-making are the most influential aspects. Their interest and attendance can however vary, depending on the agenda items, although overall there is a feeling of familiarity among members of the Forum.

Stakeholder salience has been confirmed as being informed by stakeholder attendance profiles and their frequency of attendance at Forum meetings. Their behaviour in meetings is highly influenced by stakeholders' active engagement and expression of opinions at meetings. It has emerged that local knowledge is also a key aspect to the saliency of a stakeholder in this environment.

The high familiarity among members is also reflected in the associative relationships, where approximately half of respondents have been involved in tourism in Scarborough for 10 years or more. The premise being that there is a greater concern and willingness among those Forum members to engage in tourism development activities as it in most instances not only affects personal interests but also their businesses. It has emerged that the agenda as well as opportunities for networking are the most important factors in deciding to attend Forum meetings. However, although there is a high familiarity, respondents have also been open to accept newcomers to the Forum, providing for active discussion. From the three types of associative relationships outlined, the reasons for engaging and attending meetings point to a 
Gesinnungsverein, where the association is devoted to a cause (i.e. tourism policy development in Scarborough).

Structure has emerged as an important aspect of stakeholder power encompassing internal as well as external influences. Not only is structure influenced by peer perception and peer pressure (stakeholders' patterns of attendance), but also by structural constraints in the wider tourism industry. These, for example, include the effect of the disbanding of the Regional Development Agencies in 2010, as well as local, regional and national changes to policies and funding streams.

The element of subjectivity highlights the interlinked nature of the eight elements of power in this stakeholder power conceptualisation. Different perspectives, opinions and viewpoints shape how stakeholders act. Their stakeholder role sets and embeddedness in structures (internal and external) shape stakeholder perceptions of other Forum members and can also have an effect on their attendance and engagement at meetings, which ultimately affects their intention and motivation to engage in tourism development in Scarborough.

In terms of stakeholder agency, individuals' capacity to act is influenced by their surroundings and structures. The key aspects emerging from the questionnaire are the importance of stakeholders' local knowledge, their familiarity with other Forum members, and a belief that members are working towards similar goals within the Forum to satisfy their personal and/or business interests. It has also emerged that their commitment to tourism in Scarborough is shown by their actual attendance at meetings, suggesting that a Gesinnungsverein is of importance in this seaside tourism environment.

A strong focus on and importance of local knowledge, as well as familiarity among Forum members, influence their social relations. The data show that due to these factors, word-of-mouth communication is of high importance whilst previous collective action also informs stakeholders' engagement positively within the Forum for Tourism. 
In terms of stakeholder visibility, the questionnaire data highlights a potential connection between attendance and engagement of Forum members at meetings. Attendance refers to the actual physical attendance of individuals at Forum for Tourism meetings, whereas engagement refers to individuals not only contributing at the meetings but also by email, telephone or any other kind of contact with members if meetings cannot be attended. The underlying premise being, that people who engage and attend are more powerful than people who do not engage or attend meetings, which has emerged from the findings from the questionnaire data. There is some consensus among respondents that there is an expectation to attend Forum meetings:

\footnotetext{
"I feel guilty if I am not present [at the meetings]. I feel I am letting them down.” (Respondent 4, male, aged 41-50, Market Research Executive)
}

Visibility has emerged as a key factor, as the data shows that respondents have felt that actual interaction and attendance at meetings is of importance, although there is scope for non-visible engagement. This non-visible engagement is based on stakeholder merits and expertise although they may not attend meetings.

"Yes, people are very influential, especially local businesses. Let me give you an example... Although [local business owner] does not attend as he is too busy, he is very active in tourism in Scarborough. People act together as individuals to achieve something greater.” (Respondent 5, female, aged 31-40, local business - accommodation provider)

Generally respondents have indicated that those who maybe do not attend meetings but who are regarded as having influence are locally established individuals who have a track record of being involved in the tourism industry, the local council and local business. Overall, 
visibility is informed by stakeholder role sets, subjectivity and the Gesinnungsverein as the associative relationship.

In terms of exploring the premise of attendance having an effect on an individual's power, the data from the interviews does not support this premise unequivocally. Although power is informed by attendance, the interview data also provides scope for power being influenced by non-attendance such as engagement through other means of communication, as well as people's status and reputation. In this sense, attendance is often influenced by subjective norms and perceptions in that respondents feel that they have to attend as they are expected to attend. However, it has emerged that attendance does not equal power.

In order to explore stakeholder power relationships in greater depth, respondents were specifically asked in the interviews to name five people with whom they communicated with about local tourism policy development. Purposefully, as power is such a value laden term, the term was not used in the interview for the creation of the stakeholder map. The notion behind the use of a stakeholder map was to identify stakeholder connections and their relationships within the Forum.

The data for the local Scarborough Borough have created a stakeholder network map comprising 29 vertices with eight partitions. The partitions have been chosen based on common denominators and roles among the vertices/respondents. In the stakeholder map, each vertex represents one individual person, although they have been assigned to different partitions depending on their primary role. 


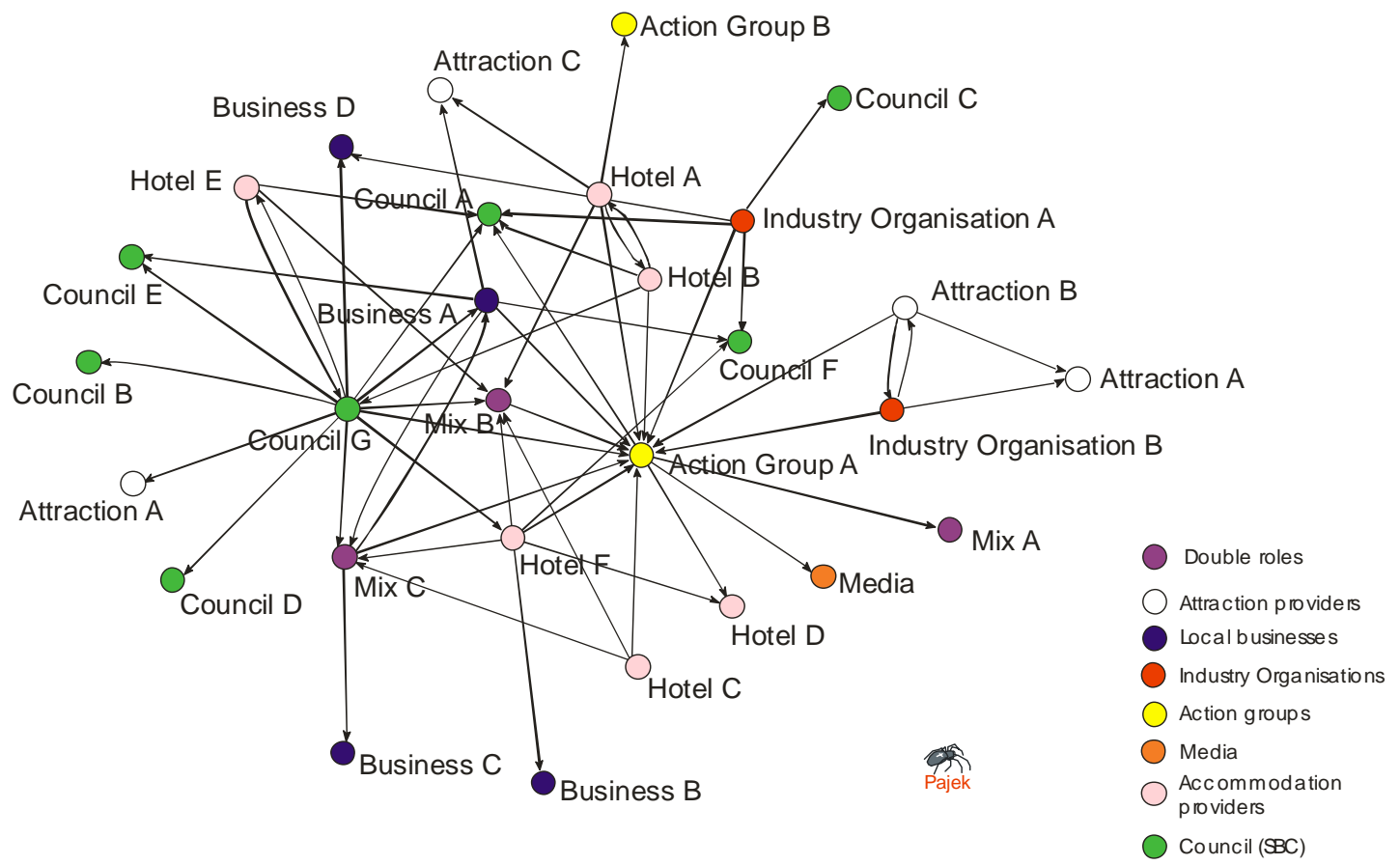

Figure 1: FFT full network map (local level)

The map shows a clear centre and periphery of the network based on the number of connections, termed degree centrality providing an indication of how many ties a vertex has as its 'neighbours' (DeNooy et al., 2005) - the more ties there are, the higher the degree of a vertex. Degree centrality in network analysis is used as a measure to consider the centre and periphery of networks and can provide an insight into the most highly connected vertices. For example, an actor who is said to have a high degree may be at the centre of the network and the hub for communication of that network. In the Scarborough stakeholder map Action Group A with a degree of 15 , is the highest degree centrality of the network.

The periphery (i.e. those actors with a low degree centrality) of the stakeholder network comprises various stakeholders from different sectors, including the media, Scarborough Council, local businesses, attraction providers, and an action group. As these are peripheral it can be argued that these are not as powerful as those stakeholders located in the centre, as they have less ties and therefore less communication with other stakeholders. The 
map indicates that some stakeholder connections are mainly one-way illustrating the importance of a central figure in such a stakeholder network. Consequently, it can be argued that stakeholder power is derived from holding a position within a network as this is based on their ties with other stakeholders as well as their engagement, which has emerged from the questionnaire and interview data. As attendance does not equal power, stakeholder power is related to stakeholder engagement and their position within a network. Utilising the eight elements of power and the stakeholder map, stakeholder power can be construed as being the ability to influence tourism policy development in the resort.

\section{Discussion and Leadership Implications}

The results of this study show that the relationship between enabling power and stakeholder engagement is influenced by several factors which emanate from the interrelatedness of stakeholders and their embeddedness within their environments and networks. Factors such as high familiarity and stakeholder interests, which have some impact upon their associative relationships, are in turn influenced by structure and social relations. The stakeholder map in particular provides a visual overview of how stakeholders are connected based on their relationships and their perceptions of why they believe someone is powerful. Visually the stakeholder map shows clear centres and peripheries providing an insight into how leadership may be informed. At a glance, the most important and perceived to be powerful stakeholders can be identified. Taken in conjunction with the findings from the questionnaire and interviews, the map confirms that aspects such as visibility, stakeholder role sets, agency, structure, associative relationships, social relations, subjectivity and stakeholder salience, influence the power of a stakeholder and their engagement in tourism. The findings also show that various stakeholders have power (through perception by others, their status, and their engagement for example) and that the level of their enabling power can 
vary depending on their position within a network. This can be circumstantial and is a dynamic interpretation of power being fluid and not a static resource based concept, enabling stakeholder engagement.

The findings of this study, set within the structuralist and functionalist perspectives and the enabling conceptualisation of power, shift our attention from the prevailing individual entity-centred and transactional forms of destination leadership (which are mainly associated with the resource dependence perspective of power and manifested by unidirectional or leader-follower exchange relationships) to the socially constructed forms of shared transformational leadership that arise from the manifold stakeholder connections and interdependencies that are embedded in their dynamic social environments (Burns, 1978; Murell, 1997; Hunt and Dodge, 2000). Within the context of local tourism policy development, shared destination leadership would see policy making as a social process shaped by interactions and dialogue with other stakeholders (Stewart, 1999; Drath, 2001). Consistent with the route concept of socially constructed forms of shared leadership, several leadership theories could be considered within the context of destination leadership, including complexity leadership (Uhl-Bien et al., 2007; Onyx and Leonard, 2010), network leadership (Balkundi and Kilduff, 2006), and distributed leadership (Bennett et al., 2003).

Given the context of this study, the complexity of stakeholder power and engagement relations that the findings of this study show and the structuralist and functionalist perspective adopted in this study, organisational leadership literature direct our attention to complexity leadership theory, particularly in view of the adaptive challenges (Heifetz et al., 2009) of English seaside resorts. Adopting a complexity leadership perspective within this context, enables viewing resorts as naturally emerging complex adaptive systems, embedded within social structures, and viewed as dynamic and interactive networks of stakeholders who engage with local tourism policy making. This approach promotes emergent, adaptive and 
enabling leadership that coexists with administrative leadership and that is capable of addressing the challenges presented by the changing destination environments (Uhl-Bien et al., 2007; Onyx and Leonard, 2010).

\section{Conclusion}

This paper examined stakeholder power and engagement within an increasingly competitive English seaside resort setting and discussed implications for destination leadership. It adopted an enabling power conceptualisation focusing on stakeholder relationships and networking and not primarily resource control or exchange. It showed that power is more than resource control and that within this context, it cannot simply be reduced to one actor having influence over another based on material factors. The study has shown that an enabling understanding of power has an effect upon stakeholder engagement and how they interact with others. It has also demonstrated that the dynamic interactions among factors such as the existence and development of a common cause (Gesinnungsverein), local knowledge and familiarity, stakeholder role sets embedded in structures influenced by stakeholders' patterns of attendance and wider internal and external environmental factors motivate stakeholder engagement and shape the destination's perceived power relationships in a way that call for adopting shared forms of destination leadership. The situational factors uncovered in this study (i.e. the increasingly changing competitive environment of an English seaside resort, tourism policy development as a common cause, and complex power and engagement relationships) indicate that complexity leadership as a form of shared valuedriven transformational destination leadership, may be a viable leadership option for Scarborough.

The results of this study provide therefore an important contribution to our understanding of stakeholder power and engagement and their implications for destination 
leadership. Since there are only a few in-depth studies that analyse destination leadership, all of which focus on destination management organisations as destination leaders, this study extends our knowledge of destination leadership and opens new interesting avenues for future studies. Specifically, it offers a greater insight into stakeholder power and engagement with local tourism policy development from the enabling power perspective, thus providing an alternative to the resource dependence and exchange perspectives that have been discussed in tourism literature. Furthermore, it demonstrates how the stakeholder power relationships and engagement, as well as specific situational factors, might influence the choice of destination leadership style. It shows that shared forms of destination leadership may be appropriate within some contexts, which may re-focus our thinking of destination leadership both from the theoretical and practical perspectives.

However, the results of this study have to be considered within its methodological limitations, including its specific context, exploratory nature and the adoption of the structuralist and functionalist perspectives. Future studies on stakeholder power, engagement and destination leadership could therefore address some of these limitations. In particular, future studies could investigate which dimensions of stakeholder power and engagement affect the destination leadership and whether particular types of destination leadership shape a stronger stakeholder engagement.

\section{References}

Adair, J. (2002), Effective Strategic Leadership, Macmillan, London.

Agarwal, S. (2002), "Restructuring seaside tourism - The resort lifecycle", Annals of Tourism Research, Vol. 29, No. 1, pp. 25-55.

Allen, A. (2003), "Power, subjectivity, and agency: Between Arendt and Foucault”, International Journal of Philosophical Studies, Vol. 10, No. 2, pp. 131-149. 
Anastasiadou, C. (2008), "Stakeholder perspectives on the European Union tourism policy framework and their preferences on the type of involvement", International Journal of Tourism Research, Vol. 10, No. 3, pp. 221-235.

Arendt, H. (1970), On Violence, Penguin Press, London.

Arendt, H. (1998), The Human Condition (second edition), The University of Chicago Press, Chicago.

Audit Commission (2009), "Regeneration inspection report: Scarborough Borough Council (June), available at: http://www.auditcommission.gov.uk/SiteCollectionDocuments/InspectionOutput/InsoectionReports/2009/scar boroughbcregeneration11jun2009REP.pdf (accessed July 2011).

Balkundi, P. and Kilduff, M. (2006), “The ties that lead: A social network approach to leadership", The Leadership Quarterly, Vol. 17, No. 4, pp. 419-439.

Bass, B. M. (1985), Leadership and performance beyond expectations, Free Press, New York.

Beatty, C. and Fothergill, S. (2003), The Seaside Economy, Centre for Regional and Social Research, Sheffield Hallam University.

Beatty, C., Fothergill, S., Gore, T. and Wilson, I. (2010), The Seaside Tourist Industry in England and Wales: Employment, economic output, location and trends, Centre for Regional and Social Research, Sheffield Hallam University.

Bennett, N. Wise, C., Woods, P.A. and Harvey, J.A (2003), Distributed Leadership: A Review of Literature. available at: http://oro.open.ac.uk/8534/1/ (accessed May 2013). 
Beritelli, P. and Laesser, C. (2011), "Power dimensions and influence reputation in tourist destinations: Empirical evidence from a network of actors and stakeholders", Tourism Management, Vol. 32, No. 6, pp. 1299-1309.

Bourdieu, P. and Wacquant, L.J.D. (1992), An Invitation to Reflexive Sociology, The University of Chicago Press, Chicago.

Burns, J.M. (1978), Leadership. New York. Harper \& Row.

Bramwell, B. and Meyer, D. (2007), "Power and tourism policy relations in transition", Annals of Tourism Research, Vol. 34, No. 3, pp. 766-788.

Briggs, A.R.J. (2005), "Middle managers in further education colleges: the new professionals", Journal of Educational Administration, Vol. 42, No. 5, pp. 586-600.

Byrd, E.T. (2007), "Stakeholders in sustainable tourism development and their roles: Applying stakeholder theory to sustainable tourism development”, Tourism Review, Vol. 62, No. 2, pp. 6-13.

Carmo, J. (2011), "Collective Agency, Obligations, Roles and Power to Act on Behalf of", available at: http://ccm.uma.pt/publications/2012/Carmo2012b.pdf (accessed September 2013).

Cooper, D.R. and Schindler, P.S. (2001), Business Research Methods (seventh edition), McGraw-Hill, New York.

Dahl, R.A. (1957), “The concept of power”, Behavioural Science, Vol. 2, No. 3, pp. 201-215. Dann, G. and Cohen, E. (1991), “Sociology and Tourism”, Annals of Tourism Research, Vol. 18, No. 1, pp. 155-169. 
Del Chiappa, G. and Presenza, A. (2013), "The Use of Network Analysis to Assess

Relationships among Stakeholders within a Tourism Destination: An Empirical Investigation on Costa Smeralda-gallura, Italy", Tourism Analysis, Vol. 18, No. 1, pp. 1-13.

Den Hartog, D.N, House, R.J., Hanges, P.J., Ruiz-Quintanilla, S.A., Dorfman, P.W. (1999), "Culture specific and cross-culturally generalizable implicit leadership theories: Are attributes of charismatic/transformational leadership universally endorsed?", The Leadership Quarterly, Vol. 10, No. 2, pp. 219-256.

De Nooy, W., Mrvar, A. and Batagelj, V. (2005), Exploratory Social Network Analysis with Pajek, Cambridge University Press, Cambridge.

Dinan, C. , Hutchison, F. and Coles, T. (2011) "The changing landscape of public sector Support for Tourism in England: insights from Local Enterprise Partnerships (LEPs) and Destination Management Organisations (DMOs) in England, available at: http://www.exeter.ac.uk/media/universityofexeter/centreforsportleisureandtourism/pdf/Chang ing_Landscape_Report_for_VisitEngland.pdf (accessed May 2013).

Doorne, S. (1998), “Power, participation and perception: An insider's perspective on the politics of the Wellington Waterfront redevelopment", Current Issues in Tourism, Vol. 1, No. 2, pp. 129-166.

Drath, W. (2001), The Deep Blue Sea: Rethinking the Source of Leadership. Jossey-Bass and Center for Creative Leadership, San Francisco.

Dredge, D. and Jenkins, J.M. (2003), “Federal-State relations and tourism public policy, New South Wales, Australia", Current Issues in Tourism, Vol. 6, No. 5, pp. 415-443. 
Evaggelia, F. and Vitta, A. (2012) "Is shared leadership the new way of management?

Comparison between vertical and shared leadership", Science Journal of Business

Management, Volume 2012 (2012), Article ID sjbm-196, Issue 2, 5 Pages, doi:

$10.7237 / \mathrm{sjbm} / 196$.

Finn, M., Elliott-White, M. \& Walton, M. (2000), Tourism and Leisure Research Methods, Harlow: Longman.

Foucault, M. (1980a), The History of Sexuality, Volume I: An Introduction, Vintage/Random House, New York.

Foucault, M. (1980b), Power/Knowledge: Selected Interviews and Other Writings 1972-77, Harvester Wheatsheaf, Hemel Hempstead.

Freeman, R.E. (1984), Strategic Management - A Stakeholder Approach, Pitman, Boston.

Fiedler, F. E. (1967), A Theory of Leadership Effectiveness, McGraw-Hill, New York.

Gale, T. (2005), "Modernism, post-modernism and the decline of British seaside resorts as long holiday destinations: A case Study of North Rhyl, North Wales", Tourism Geographies, Vol. 7, No. 1, pp. 86-112.

Go, F.M. and Gover, R. (2000), "Integrated quality management for tourist destinations: a European perspective on achieving competitiveness", Tourism Management, Vol. 21, No. 1, pp. 79-88.

Granovetter, M. (1985), "Economic Action and Social Structure: The Problem of Embeddedness", The American Journal of Sociology, Vol. 91, No. 3, pp. 481-510. 
Hallinger, P. (2003), "Leading educational change: reflections on the practice of instructional and transformational leadership", Cambridge Journal of Education, Vol. 33, No. 3, pp. 329352.

Hankinson, G. (2012), “The measurement of brand orientation, its performance impact, and the role of leadership in the context of destination branding: An exploratory study", Journal of Marketing Management, Vol. 28, No. 7-8, pp. 974-999.

Haven-Tang, C. and Jones, E. (2012), “Local leadership for rural tourism development: A case study of Adventa, Monmouthshire, UK", Tourism Management Perspectives, No. 4, pp. $28-35$.

Heifetz, R., Grashow, A. and Linsky, M. (2009), Diagnose the Adaptive Challenge: Understanding the Human Dimensions of Change, Harvard Business Press Chapters.

Hersey, P., and Blanchard. K.H. (1969), "Life cycle theory of leadership", Training and Development Journal, Vol. 23, No. 2, pp. 26-34.

Hersey, P., and Blanchard, K.H. (1977), Management of Organization Behavior: Utilizing Human Resources (3rd ed.). Prentice-Hall, Englewood Cliffs, NJ.

Hunt, J., and Dodge, G. E. (2000), “Leadership déjà vu all over again”, The Leadership Quarterly Review of Leadership, Vol. 11, No. 4, pp. 435-458.

Kanter, R.M. (1983), The Change Masters: Corporate Entrepreneurs at Work. Counterpoint, London.

Kearins, K. (1996), "Power in organisational analysis: delineating and contrasting a Foucauldian perspective”, Electronic Journal of Radical Organisation Theory, Vol. 2, No. 2, pp. 1-25. 
Kimbu, A. N. and Ngoasong, M.Z. (2013), “Centralised decentralisation of tourism development: A network perspective”, Annals of Tourism Research, Vol.40, pp. 235-259.

Kotter, J.P. (1990), “What leaders really do", Harvard Business Review, Vol. 68, No. 3, pp. 103-111.

Kotter, J.P. (1995), “Leading change: Why transformation efforts fail”, Harvard Business Review, Vol. 73, No. 2, pp. 59-67.

Kotter, J.P. (1999), What leaders really do, Harvard Business Press.

Kotter J.P. (2007), “Leading Change”, Harvard Business Review, Vol. 85, No. 1, pp. 96-103. Krausz, R.R. (1986), "Power and leadership in organizations”, Transactional Analysis Journal, Vol. 16, No. 2, pp. 85-94.

Knippenberg, D. van and Sitkin, S.B. (2013) “A critical assessment of charismatictransformational leadership research: back to the drawing board?", The Academy of Management Annals, Vol. 7, No. 1, pp. 1-60.

Lehmann, D. R. \& Hulbert, J. (1972), “Are three-point scales always good enough?”, Journal of Marketing Research, Vol. 9, No. 4, pp. 444-446.

Locke, W. (2007), “Higher education mergers: integrating organisational cultures and developing appropriate management styles", Higher Education Quarterly, Vol. 61, No. 1, pp. 83-102.

May, T. (2001), Social Research: Issues, methods and process, (third edition), Buckingham: Open University Press. 
Mitchell, R.K., Agle, B.R. and Wood, D.J. (1997), “Toward a theory of stakeholder identification and salience: defining the principle of who and what really counts", Academy of Management Review, Vol. 22, No. 4, pp. 853-886.

Murrell, K. L. (1997), "Emergent theories of leadership for the next century: Towards relational concepts”, Organization Development Journal, Vol. 15, No. 3, pp. 35-42.

North Yorkshire County Council (2010), “2009 Parish population estimates, available at: http://www.northyorks.gov.uk/CHttpHandler.ashx?id=11401\&p=0 (accessed July 2011).

Northouse, P.G. (2004), Leadership. Theory and Practice. Sage, Thousand Oak.

Onyx, J. and Leonard, R.J. (2010), “Complex systems leadership in emergent community projects". Community Development Journal, Vol. 46, No. 4, pp. 493-510.

Ottenbacher, M.C. and Harrington, R.J. (2013), “A Case Study of a Culinary Tourism Campaign in Germany: Implications for Strategy Making and Successful Implementation”, Journal of Hospitality and Tourism Research, Vol. 37, No. 1, pp. 1-15.

Parsons, T. (1968), The Structure of Social Action (second edition), Free Press, New York. Patton, M. Q. (2002), Qualitative research and evaluation methods, Thousand Oaks, C.A: Sage.

Pearce, C.L. (2004) “The future of leadership: Combining vertical and shared leadership to transform knowledge work" Academy of Management Perspectives, Vol. 18, No. 1, pp. 4757.

Pfeffer, J. (1981), Power in Organizations, Pitman, Marshfield, MA. 
Pforr, C. (2006), “Tourism policy in the making: an Australian network study", Annals of Tourism Research, Vol. 33, No. 1, pp. 87-108.

Powell, R.B., Cuschnir, A. and Peiris, P. (2009), "Overcoming governance and institutional barriers to Integrated Coastal Zone, marine protected area, and tourism management in Sri Lanka", Coastal Management, Vol. 37, No. 6, pp. 633-655.

Pechlaner, H., and Tschurtschenthaler, P. (2003), "Tourism policy, tourism organisations and change management in Alpine regions and destinations: a European perspective", Current Issues in Tourism, Vol. 6, No. 6, pp. 508-539.

Reed, M.G. (1997) "Power relations and community-based tourism planning”. Annals of Tourism Research, Vol. 24, No. 3, pp. 566-591.

Rowley, T.J. (1997), “Moving beyond dyadic ties: A network theory of stakeholder influences", Academy of Management Review, Vol. 22, No. 4, pp. 887-910.

Ruhanen, L. (2013), “Local government: facilitator or inhibitor of sustainable tourism development?”, Journal of Sustainable Tourism, Vol. 21, No. 1, pp. 80-98.

Scarborough Borough Council (2004), “20/20 vision: a strategic investment plan for Scarborough Borough, available at:

http://www.scarborough.gov.uk/PDF/2020\%20Vision\%20\%20Strategic\%20Investment\%20Plan\%20for\%20Scarborough\%20Borough.pdf (accessed July 2011).

Scott, N., Baggio, R. and Cooper, C. (2008), Network Analysis and Tourism: From Theory to Practice, Clevedon: Channel View 
Sheehan, L.R. and Ritchie, J.R.B. (2005), "Destination stakeholders - exploring identity and salience", Annals of Tourism Research, Vol. 32, No. 3, pp. 711-734.

Sibeon, R. (1999), "Agency, structure, and social chance as cross-disciplinary concepts”, Politics, Vol. 19, No. 3, pp. 139-144.

Stevenson, N., Airey, D. and Miller, G. (2008), “Tourism policy making: the policymakers' perspective", Annals of Tourism Research, Vol. 35, No. 3, pp. 732-750.

Stewart, R. (1999), “Some observations concerning Sayles' managerial behaviour”, The Leadership Quarterly, Vol. 10, No. 1, pp. 17-20.

Svensson, B., Nordin, S. and Flagestad, A. (2005) "A governance perspective on destination development-exploring partnerships, clusters and innovation systems", Tourism Review, Vol. 60, No. 2, pp. $32-37$.

Swedberg, R. (2005), “Can there be a sociological concept of interest?”, Theory and Society, Vol. 34, pp. 359-390.

Tannenbaum, R., and Schmidt, W. H. (1958), "How to Choose A Leadership Pattern”, Harvard Business Review, Vol. 36, No. 2, pp. 95-101.

Teddlie, C. \& Tashakkori, A. (2009), Foundations of Mixed Methods Research: Integrating Quantitative and Qualitative Approaches in the Social and Behavioural Sciences, Thousand Oaks, CA: Sage Publications.

Thiele, L.P. (1997), Thinking Politics: Perspectives in Ancient, Modern, and Postmodern Political Theory, Chatham House Publishers, Chatham, New Jersey. 
Timur, S. and Getz, D. (2008) "A network perspective on managing stakeholders for sustainable urban tourism", International Journal of Contemporary Hospitality Management, Vol. 20, No. 4, pp. $445-461$.

Treuren, G. and Lane, D. (2003), “The tourism planning process in the context of organised interests, industry structure, state capacity, accumulation and sustainability, Current Issues in Tourism, Vol. 6, No. 1, pp. 1-22.

Uhl-Bien, M., Marion, R. and McKelvey, B. (2007), “Complexity leadership theory: shifting leadership from the industrial age to the knowledge era", The Leadership Quarterly, Vol. 18, pp. 298-318.

Varra, L., Buzzigoli, C. and Loro, R. (2012) "Innovation in destination management: social dialogue, knowledge management processes and servant leadership in the Tourism Destination Observatories", Procedia - Social and Behavioral Sciences, Vol. 41, pp. 375-385.

Wang, S., Yamada, N., and Brothers, L. (2011), “A Case study: discussion of factors and challenges for urban cultural tourism development", International Journal of Tourism Research, Vol. 13, No. 6, pp. 553-569.

Welcome to Yorkshire (2011), Tourism Statistics, email communication (02/09/2011).

Woolley, C.M. (2009), "Meeting the mixed methods challenge of integration in a sociological study of structure and agency", Journal of Mixed Methods Research, Vol. 3, No. 1, pp. 7-25.

York and North Yorkshire LEP (2010), A York and North Yorkshire Local Enterprise Partnership, available at: http://www.ynypu.org.uk/documents/YNY\%20LEP\%20response\%20to\%20BIS.pdf (accessed July 2011). 